\title{
PENGEMBANGAN PEMIKIRAN KEAGAMAAN DI SULAWESI SELATAN (KASUS FATHUL MUIN KOTAMADYA UJUNGPANDANG)
}

\author{
H. ABD. AZIS AL BONE
}

\section{PENDAHULUAN}

Salah satu gejala sosial yang menonjol dewasa ini adalah munculnya pluralisme agama. Pluralisme agama dibarengi dengan timbulnya pluralisme teologi, filsafat, sistem nilai idiologi dan pandangan hidup. Peter Berger melukiskan pluralisme sebagai situasi yang di dalamnya tersedia lebih dari satu pandangan hidup bagi warga masyarakat, yaitu situasi persaingan diantara pandangan hidup (Berger, dalam Sastraprateja, 1986:33). Kompetisi berbagai pandangan hidup yang tumbuh dalam masyarakat, dapat terjadi diantara kelompokkelompok yang mengikuti suatu faham keagamaan tertentu. Terlepas dari apakah faham keagamaan itu merupakan produk dari pemikiran dan pemahaman yang sumbernya diambil dari teks-teks kitab suci ; atau paham keagamaan yang sudah bercampur baur dengan tradisi lokal.

Di Sulawesi Selatan, dewasa ini sedang berkembang salah satu kelompok keagamaan, yang dalam aktivitas sehariharinya kelihatan berbeda dengan pola sikap masyarakat muslim lainnya. Perbedaan itu, antara lain, menyangkut sikap ekslusivisme, memisahkan diri dari jamaah atau peribadatan umat Islam lainnya, dan mempunyai pandangan dan interpretasi berbeda terhadap teks-teks kitab suci. Kelompok ini bergabung dalam Yayasan Fathul Muin yang berba- sis di Masjid Widhatul Ummah, Jalan Abdullah Daeng Sirua Nomor 57 Kelurahan Persiapan Tamamaung Kecamatan Panakkukang Ujungpandang.

\section{SEJARAH PERKEMBANGAN- NYA.}

Gagasan membentuk Yayasan Fathul Muin, dimotivasi oleh seorang ulama karismatik di Ujungpandang bernama KH Fathul Muin Daeng Maggading. Semasa hidupnya, Fathul Muin terkenal sebagai mubalig yang cenderung sangat konservatif dalam memahami dan mengamalkan ajaranajaran Islam. Tidak diketahui, apakah nama Fathul Muin merupakan nama yang dibawa sejak kecil, atau nama ini populer, setelah dia menjadi ulama yang mempunyai banyak jamaah. Yang jelas, nama Fathul Muin diambil dari salah satu Kitab yang menjadi rujukan para ulama, terutama dari kalangan Muhammadiyah.

KH Fathul Muin Daeng Maggading semasa hidupnya membuka majlis pengajian berkala. Setiap majlis digelar diikuti jamaah dalam jumlah cukup banyak. Dia meninggal di Ujungpandang pada tahun 1984.

Yayasan Fathul Muin dibentuk pada tanggal 18 Juni 1988 berdasarkan akta notaris No: 20 dan kemudian secara 
resmi ter'daftar di Pengadilan Negeri Kelas I Ujungpandang NO.47 tanggal 22 Juni 1988. Akta pendirian yayasan ini terdiri dari 14 pasal, meliputi : nama, yayasan, kedudukan, waktu berdirinya, maksud dan tujuan, usaha-usaha yang dilakukart, kekayaan, keanggotaan, hak dan kewajiban anggota, kepengurusan, Pemberhentian, musyawarah, dewan pengawas .pembubaran dan ketentuan umum.

Melihat kelengkapan akta berdirinya, Yayasan Fathul Muin secara resmi dibangun untuk melanjutkan misi pengajian KH Fathul Muin Daeng Maggading. Pengajian ini, yang harus dilestarikan, selain lembaganya sendiri, juga spesifikasi, terutama berkaitan dengan pola-pola kajian dan cara menginterpretasi nash-nash Al Quran. Berdasarkan akta ini, sebenarnya, Yayasan Fathul Muin cukup terbuka, dan menerima semua pihak menjadi anggota sepanjang bisa beradaptasi dengan kegiatan di pengajian-pengajian yayasan. Akan tetapi, karena pada umumnya anggota Yayasan, setelah aktif dalam pengajian, cenderung menjadi ekslusif sehingga organisasi ini, oleh masyarakat di sekitarnya dianggap, semacam kelompok jamaah minoritas yang berusaha mengamalkan ajaran agama secara tekstual dan harpiah.

Menurut salah seorang tokoh yayasan, ide untuk membentuk organisasi secara permanen dalam Yayasan Fathul Muin ini, antaralain karena adanya kekuatiran pengikut atau murid Daeng Maggading, bahwa ajarannya bakal hilang setelah KH Fathul Muin meninggal dunia. Selain itu, ide ioni di matangkan oleh munculnya perbedaan pendapat tentang berbagai masalah keagamaan di tengah-tengah masyarakat, tidak lama setelah tokoh Fathul Muin meninggal dunia. Murid-murid Daeng Maggading, yang semasa beliau masih hidup bersatu dalam pengajian di Yayasan Takmilur, Masjid Ta'mirul di Ujungpandang. Karena timbulnya perbedaan pendapat diantara beberapa murid utama, sehingga kelompok ini terbagi dua. Kelompok pertama bertahan di Masjid Takmirul, dan kelompok kedua memisahkan diri di Masjid Widhatul Ummah jalan Abdullah Daeng Sirua sampai sekarang. Masjid Widhatul Ummah ini, dibangun kelompok kedua tadi, dan menjadi basis pengkajian ajaran Fathul Muin baru di Ujungpandang.

\section{AKTIVITAS-AKTIVITAS YAYASAN}

Yayasan Fathul Muin yang berlokasi di Jalan Abdullah Daeng Sirua, dua tahun sejak berdirinya, yaitu tahun 1990, resmi mengadakan kegiatan organisasi. Antara lain, kegiatan dakwah, pembinaan kader-kader muda Islam, dan lembaga pendidikan. Untuk menghidupi Yayasan, lembaga ini juga bergerak di bidang ekonomi, seperti membuka bidang usaha yang bisa menghimpun dana untuk kepentingan yayasan.

Lebih jelasnya, rincian aktivitasnya dapat di deskripsi sebagai berikut :

1. Pembinaan kualitas sumber daya manusia (SDM)

Sejak tahun 1990 Yayasan Fathul Muin telah mengirim sejumlah santri hasil binaan selama dua tahun. Santrisantri tersebut dikirim ke HQ (Institut Ilmu Al Quran ) di Jakarta . Santri 
tersebut dikirim dengan biaya penuh dari Yayasan, walaupun jumlahnya cukup banyak. Sejak tahun 1990 telah di kirim 27 santri putra dan 25 santri putri ke berbagai lembaga pembinaan mubalig di Jakarta. Jaringan yayasan dengan lembaga pendidikan di luar negeri juga cukup mantap. Terbukti dengan kemampuan Yayasan menugas belajarkan 8 orang kadernya ke Universitas Islam Madinah. Dua diantaranya telah kembali ke Indonesia, dan sekarang mengabdi di Yayasan sebagai mubalig dan guru yayasan untuk berbagai lembaga pendidikan yang di miliki kelompok ini.

\section{Pendidikan.}

Data yang diperoleh dari Sekretariat Yayasan Fathul Muin menunjukan, organisasi ini sejak tahun 1992 telah membina 9 buah Raudhatul Athfal (Taman Kanak-kanak) AlQuran dan Taman Pendidikan AlQuran. Sembilan TKA dan TPA ini tersebar di Ujung Pandang, Sungguminasa, Panciro Gowa, Enrekang dan beberapa tempat lainnya di Kabupaten Gowa. Jumlah santri yang sekarang belajar di TPA dan TKA tercatat 522 orang.

Kiprah Yayasan tidak saja membuka lembaga pendidikan agama, tetapi juga peduli terhadap upaya peningkatan kualitas sumber daya manusia. Untuk itu, Yayasan ini sejak tahun 1995, membuka Pendidikan Guru Taman Kanak-kanak ( PGTKA) setingkat DI. PGTKA ini bersifat temporer, dan pelaksanaannya, menggunakan model pelatihan dengan target waktu yang relatif singkat.
Mengantisipasi kurangnya ulama yang disinyalir sejumlah tokdh agama beberapa waktu lalu, Yayasan Fathul Muin juga membuka Lembaga Pendidikan Bahasa Arab, dengan tiga tingkatan, yaitu kelas A dan B tingkat I dan II peserta khusus laki-laki, dan kelas D tingkat I untuk wanita. Kelas C pesertanya bergabung antara laki-laki dan wanita. Mapannya Kelas kelas pendidikan Bahasa Arab ini karena out put nya yang berprestasi di janjikan menjadi utusan Yayasan ke Universitas Islam Madinah.

Di bidang dakwah, Yayasan Fathul Muin menyebar 9 majlis taklim di lima Kecamatan di Kotamadya Ujungpandang. Juga mengifim mubalignya untuk mengadakan dakwah Islamiah di berbagai daerah tingkat II se Sulawesi Selatan. Yang menarik, karena semua program yang dilaksanakari dibiayai Yayasan secara mandiri dan tidak ada ketergantungan dengan pihak lain, khusus menyangkut pendanaan.

Majlis taklim yang berkembang di daerah, koordinasinya bekerjasama dengan pengurus Muhammadiyah setempat.

\section{POKOK-POKOK AJARAN YANG DIKEMBANGKAN.}

1. Masalah Doktrin.

Salah seorang tokoh Yayasan Fathul Muin berpendapat bahwa Iman kepada Allah, merupakan suatu penyerahan total tanpa syarat. Penyerahan secara total ini, tidak saja terbatas dalam pengakuan lisan dan penyaksian hati, tetapi yang lebih penting, adalah 
implementasinya dalam kehidupan sehari-hari. Yayasan ini menganggap kepercayaan terhadap rukun iman atas enam aspek, masih belum final. Ada peluang untuk melakukan reinterpretasi pada konsep konsep keimanan, sebagaimana yang telah di yakini umat Islam selama ini. Pandangan ini juga menunjukan bahwa, jumlah rukun iman seharusnya bersifat konseptual, dalam arti bisa di tambah dan dikurangi sepanjang hal itu mempunyai dasar rujukan dalam teks teks agama.

Bagi anggota Yayasan, substansi dari rukun iman, dapat di rangkum dalam, percaya kepada Allah dan apa yang datang dari padanya. Lebih jelas, rukun iman dapat di peras dari enam menjadi tiga : yaitu, (1) percaya kepada Allah ( termasuk didalamnya percaya kepada isi Al Quran, pemberitaan kitab-kitab lain dalam Al Quran).(2), Percaya kepada Rasul (berarti percaya kepada Sunnah Rasul Nabi Muhammad SAW ), dan (3) Percaya kepada yang gaib ( termasuk percaya kepada hari akhirat, kepada takdir baik dan buruk).

Konsep rukun iman yang tiga bahkan masih bisa diperas menjadi dua, yakni (1) Percaya kepada Allah, dan (2) Percaya kepada yang gaib. Apabila masih mau di rangkum lebih singkat, akhirnya menjadi satu, cukup dengan Percaya kepada Allah saja.

Yayasan ini sangat elastis dalam memahami ajaran ajaran agama. Pola penyingkatan rukun iman ke dalam satu substansi yaitu hanya dengan percaya kepada Allah dengan catatan, inti lima rukun iman yang dipahami secara konvensional, sudah terangkum dalam satu kalimat singkat saja.

2. Pelaksanaan Ibadah.

Ada kecenderungan, yayasan Fathul Muin menafsirkan mamfaat sholat secara perorangan. Walaupun sholat perorangan dibenarkan sepanjang hal itu mempunyai alasan-alasan yang dapat di terima secara dalil nakliah. Oleh karena itu, anggota yayasan ini, mewajibkan sholat berjamaah di masjid. Kalau tidak ada masjid di sekitar tempat tinggal, itupun harus dilakukan secara berjamaah. Toleransi terhadap sholat sendirian hanya dibolehkan dalam kasus yang sangat darurat, seperti, tidak ada masjid, tidak ada orang sholat dalam masjid, dalam keadaan musafir, atau tidak ada teman seagama. Prinsip ini di dasarkan pada pengalaman hidup Rasulullah SAW yang sepanjang hidupnya selalu sholat berjamaah, baik dalam keadaan damai maupun dalam suasana perang. Demikian pula permulaan sholat fardu, ketika Rasulullah kembali dari Isra' Mi'raj, beliau diimami oleh Jibril.

Beberapa ketentuan yang harus dipatuhi kelompok ini berkaitan dengan pelaksanaan sholat, antara lain,

a. Tidak dibenarkan menggunakan sajadah atau tikar tempat sujud kecuali kalau tikar dapat menutupi semua ruangan masjid.

b. Dalam menyusun shop berjamaah, setiap jamaah harus selalu berdempetan, saling bersentuhan antara siku-kaki .

No. 12 Th.VII Juli/Desember 1995 
c. Selesai sholat berjamaah, tidak ada doa bersama yang dipimpin oleh imam. Masing-masing jamaah boleh berdoa secara mandiri. Dalam berdoa tidak mengangkat tangan. Pada waktu sholat tidak membaca basmalah, boleh saja membaca basmalah tapi tidak di lapalkan, cukup hanya dalam hati.

d. Jamaah wanita, tidak diikutkan sholat berjamaah. Alasannya, tidak ada tabir pembatas. Padahal dalam sholat tidak boleh saling melihat antara laki dan wanita kecuali muhrim.

e. Membaca doa qunut waktu subuh, dianggap bid'ah (dosa). Apabila selesai berdoa dibolehkan membaca doa termasuk doa qunut.

f. Sholat sunat yang mengikuti fardhu dilaksanakan ditempat sholat berjamaah, sedang sholat sunat lainnya di laksanakan di rumah, kecuali bila rumah berdampingan dengan masjid maka sholat tahajjud dibolehkan.

g. Sholat tarwih tidak ada nashnya dalam hadis. Yang ada sholat tahajjud. Di bulan Ramadhon disebut Qiyamuramadhon. Boleh berjamaah boleh tidak. Tehtang sholat tarwih ini, ada* perbedaan pendapat diantara murid Fathul Muin. Ada pendapat, bahwa shalat tahajud dan sholat tarwih sama, sebaliknya ada yang mengatakan berbeda dan saling berdiri sendiri.

h. Sholat Id seyogianya dilakukan di tempat yang lebih luas dari lapangan. Idealnya dilaksanakan di masjid.
Takbir 9 kali dalam khutbah Id tidak menjadi syarat sahnya khutbah. Walaupun hanya satu kali takbir, khotbah sudah sah. Sholat Id, dengan takbir tujuh kali pada rakaat pertama, dan lima kali pada rakaat kedua, dalilnya lemah dan tidak bisa dijadikan pegangan.

i. Pemakaian jilbab hukumnya wajib. Setiap wanita baliq,tidak diperkenankan membuka aurat. Kaum wanita dalam penampilan seharihari, harus memakai kaos kaki, diutamakan memakai cadar (penutup mulut dan hidung) sehingga yang kelihatan hanya kedua bola mata. Warna yang di kehendaki, adalah warna hitam dan abu-abu tua. Jamaah laki-laki diutamakan tidak memakai pakaian berwarna warni. Waktu sholat seyogianya memakai baju warna putih, termasuk pici. Kalau menggunakan sarung dalam sholat sebaiknya kelihatan tumit dengan sempurnah.

j. Berjabat tangan wanita dan laki laki yang bukan muhrim menurut Yayasan ini, adalah dosa. Menghadiri pesta perkawinan tidak dibolehkan berjabat tangan dengan pengantin wanita. Dalam pesta perkawinan, tidak dibolehkan mempelai laki laki dan wanita duduk bersanding. Keduanya harus di pisahkan dengan dinding pemisah.

\section{PELAKSANAAN PENGAJIAN}

Kegiatan da'wah bukan saja dalam bentuk pengiriman mubalig ke daerahdaerah tingkat II, Yayasan Fathul Muin juga menggelar pengajian dua kali se- 
minggu. Setiap fnalam Senin, malam Jumat dan malam Rabu, selalu diselenggarakan pengajian di Masjid Widhatul Ummah. Demikian juga pada jumat sore, setelah sholat ashor, juga diadakan pengajian yang diikuti peserta wanita. Dibanding pengajian malam hari ( malam senin, malam rabu dan malam jumat) dengan sore harinya, maka kegiatan di malam hari jauh lebih ramai. Yang menarik, karena dari semua aktivitas pengajian ini lebih banyak diikuti anak-anak muda. Daya tarik majlis pengajian kepada anak anak muda, antara lain, karena materi yang di jadwalkan selalu mengacu pada masalah-masalah yang aktual pada waktu itu. Sehingga mengundang rasa ingin tahu peserta pengajian, yang menyebabkan mereka datang beramai-ramai menghadirinya. Mubalig yang membawakan pengajian pada umumnya dari anggota Yayasan, dan ada juga dari luar yayasan. Nama-nama mubalig yang biasa mengisi pengajian mingguan ini, sebagai berikut :

1. H.Muh Said Samad.LC (Dosen UMI)

2. H.Takdir, LC

3. Ir.Nursalam ( Unhas )

4. Ir Qasim Saguni

5. Kamaluddin Sukku (Pesantren Macopa Maros)

6.Arif Marzuki (Pesantren Macopa Maros )

7.Ir.Fuad Rumi ( Dosen UMI).

Secara umum, keterlibatan ke dalam Yayasan Fathul Muin diatur berdasarkan Anggaran Dasar dan Peraturan Rumah Tangga . Peserta yang sering ikut kegiatan, seperti pengajian, dan ceramah umum lainnya, terdiri dari anggota tetap, dan selainnya simpatisan yang tidak terdaftar secara resmi.
Dari semua jenis usaha yang dikelola, baik berkaitan dengan kegiatan ekonomi, dakwah dan pelaksanaan ibadah di Masjid Widhatul Ummah, pada umumnya di tangani secara langsung oleh anggota tetap. Kriteria anggota tetap, antara lain harus mempunyai nomor identitas yayasan (NIU). Dengan NIU ini, pimpinan Yayasan mudah mengontrol anggota dan melakukan rekrutmen terhadap pos pos yayasan yang sifatnya operasional. Yayasan Fathul Muin, secara kolektif di kelola oleh 51 orang pengurus utama, terdiri dan pengurus dan pembina Lembaga Pembinaan Taman Kanak-kanak Al Quran (LPTKA) dan 44 orang lainnya sebagai tenaga pelaksana. Tenaga pelaksana ini, ada yang ditugaskan di Ujung Pandang, ada pula yang ditempatkan di daerah daerah, dimana lembaga operasional kelompok yayasan berada.

\section{VI.DESKRIPSI ANALISIS}

Yayasan Fathul Muin, sebenarnya, adalah suatu lembaga yang berusaha menyebar luaskan dakwah Islamiyah secara terprogram dan sistimatik. Munculnya yayasan ini, pada tahun 1988, tidak populer bahkan jarang diketahui masyarakat umum, sampai mereka dapat mengembangkan diri dalam berbagai kegiatan ekonomi, dan dakwah serta pendidikan sekaligus.

Berbeda dengan lembaga dakwah lain yang sejak lahirnya sudah sarat publikasi. Yayasan Fathul Muin, memilih alternatif lain, yakni dengan melakukan dakwah secara bertahap.Yayasan diperkenalkan kepada jamaah secara sistimatik melalui pengajian, yang jumlah pesertanya terus bertambah dari waktu ke 
waktu. Sadar, bahwa aktivitas yayasan tidak akan bisa berkembang baik tanpa dukungan dana, pengurus dan anggota Fathul Muin mengantisipasinya dengan membuka usaha-usaha legal di sektor perkebunan, kios pupuk dan obat tanaman, toko buku, serta usaha kayu dan pembuatan koseng. Dana yang dihimpun dari kegiatan ekonomi ini, mampu membiayai semua program dakwah, pendidikan, serta pengiriman mahasiswa ke luar negeri.

Melihat spesifikasi, dalam bentuk prinsip dasar yang berkaitan dengan masalah-masalah agama, pada dasarnya, yayasan ini tidak bisa dikategorikan sebagai kelompok sempalan, manakala pengertian sempalan di kaitkan dengan kelompok yang secara perinsip menyimpan dari doktrin agama sebagaimana dipahami dari teks-teks Kitab Suci. Apa yang dilakukan di yayasan ini, adalah suatu upaya untuk memahami secara luwes dari nash-nash Al Quran dan hadis Rasulullah SAW. Berbeda dengan gerakan reformasi atau tajdid, Yayasan Fathul Muin menekankan, kepada anggotanya agar tidak kaku memahami ajaran agama. Ini dibuktikann dengan sikap yang memeras rukun iman dari enam menjadi tiga, dua dan kemudian menjadi satu. Walaupun rukun iman dapat di peras menjadi satu, yaitu hanya percaya kepada Allah SWT, tetapi dalam konsep itu, lima inti rukun iman lainnya harus bisa terangkum di dalamnya.

Dilain pihak, kelompok ini, menganjurkan jamaahnya berprilaku agama secara konservatif. Berusaha mencontoh prilaku Rasulullah, adalah salah satu rujukan. Hal ini dapat di lihat dari penekanan, wajibnya sholat jamaah kecuali dalam hal-hal yang bersifat darurat. Argumentasinya jelas kepada sejarah Rasulullah, yang sepanjang hidupnya selalu sholat berjamaah. Indikator sikap ortodoksi juga nampak ketika jamaah wanita diperintahkan mengenakan busanah serba tertutup. Tidak diperkenankan memperlihatkan aurat, termasuk wajah dan hidung. Selain kedua mata, semua wajah wanita kalau keluar dari rumah harus tertutup dengan cadar. Kelanjutan dari seruan menutup aurat, Yayasan Fathul Muin menolak, jabat tang an antara laki-laki dan wanita yang bukan muhrim. Bahkan, di pesta perkawinan mereka menolak kedua mempelai duduk bersanding. Berjabat tangan dengan wanita bukan muhrim adalah dosa.

Yayasan ini, berusaha untuk "mengislamkan " tradisi budaya yang selama ini dianggap telah mengintervensi doktrin agama terlalu jauh. Prinsip dasar agama yang berhubungan dengan ibadah harus di pisahkan dari ketentuan tradisi lokal. Dan semua rujukan menyangkut ibadah, harus merujuk pada Al Quran dan Sunnah Rasulullah. Sepanjang ada dasarnya dalam kedua sumber hukum Islam (Al-Quran dan Sunnah Rasulullah), maka hal tersebut bisa di terima.Ada beberapa target utama Yayasan Fathul Muin, di dalam dakwah: 1. Melakukan koreksi terhadap ajaran agama yang sudah mengalami intervensi adat, 2. Meluruskan aqidah dan memperbaiki akhlak umat, 3. Meluruskan dan menyempurnakan pelaksanaan sholat, dan 4. Mengintensifkan pendidikan agama terhadap anak-anak dan remaja.

Menjaga agar sikap jamaah terhadap masalah-masalah agama tidak sepihak, 
para pembina pengajian selalu menjadwalkan materi khusus dengan terlebih dahulu mengemukakan khilapiah antara para ulama. Mereka memperkenalkan bermacam-macam pendapat ulama tentang suatu masalah, dan kemudian mengambil kesimpulan sebagai sikap yayasan.

Sikap yang lain dibanding dengan masyarakat Islam umumnya dapat di lihat dari ciri-ciri sebagai berikut :

1. Di dalam jamaah masjid, tidak ada wanita.

2. Tidak diperkenankan menggunakan sajadah.

3. Mayoritas jamaah menggunakan celana panjang.

4. Usia rata-rata jamaah maksimal 40 tahun.

5. Lebih banyak jamaah memakai pici berwarna putih.

6. Deretan shop di waktu sholat harus berdempetan,

7. Tidak ada doa bersama sesudah sholat.

8. Kalau berdoa tidak mengangkat tangan.

\section{PERSEPSI UMAT ISLAM DI SEKITAR MASJID WIDHATUL UMMAH}

Bagaimana persepsi masyarakat (umat Islam) " $\mathrm{y}^{\mathrm{an}} \mathrm{g}$ bertempat tinggal di sekitar masjid Widhatul Ummah, sebagai pusat kegiatan Yayasan Fathul Muin, dapat di ketahui dari pengakuan beberapa informan .

Ada beberapa informan, yang sampai penelitian ini diadakan tidak mengetahui kegiatan apa saja yang di adakan di dalam masjid itu. Dia juga tidak tahu, siapa yang menjadi aktor atau pelaku dalam kegiatan itu. Yang jelas, setiap hari, mereka melihat rombongan pengajian yang kebanyakan dari anak-anak muda datang ke masjid dengan menggunakan mobil, motor dan sebagainya. Ada satu informan yang mencoba menerka, dengan mengemukakan bahwa kegiatan di masjid itu di koordinasi oleh sekelompok organisasi Islam. Ada pula jamaah yang menganggap, kegiatan di masjid itu, perpaduan antara dua kelompok sempalan dalam Islam. Kecenderungan beberapa informan yang mengidentikan dengan Islam Jamaah, dengan melihat cara berpakaian wanita peserta pengajian yang menutup seluruh tubuh, termasuk wajah kecuali dua bola mata. Demikian pula penggunaan kaos kaki bagi jamaah wanita. Meskipun banjir di jalanan, mereka tidak akan membuka kaos kakinya.

Beberapa jamaah yang diwawancarai, ada yang merigaku tidak pernah mengikuti sholat jamaah bersama mereka, karena merasa ragu apakah kelompok ini, tidak menolak kehadiran jamaah yang berasal dari luar. Apalagi, setelah melihat keunikan yang ada di kalangan pengunjung pengajian. Melihat jamaah mengenakan pakaian warna putih, memeliharajanggot dan sebagainya, merupakan pemandangan rutin di sekitar kompleks masjid widhatul ummah.

Pada tahun 1984 yang lalu, ada seorang informan yang bertempat tinggal di sekitar masjid, mencoba mengikuti sholat jamaah bersama, tetapi dia tidak mampu melakukannya karena ayat-ayat yang dibaca Imam sangat panjang, demikian juga diwaktu rukuk dan sujud. 
PENGEMBANGAN PEMKIRAN KEAGAMAAN DI SULAWESI SELATAN

(KASUS FATHUL MUIN KOTAMADYA UJUNGPANDANG)

\section{PENUTUP}

Demikianlah deskripsi hasil temuan penelitian yang diadakdn terhadap Yayasan Fathul Muin di Jalan Abdullah Daeng Sirua. Satu kelompok jamaah yang berusaha memahami Islam secara ortodoksi tetapi membuka diri terhadap perlunya reinterpretasi ajaran agama, pada kasus kasus yang dianggap penting.

Yayasan Fathul Muin, sampai saat penelitian ini di laksanakan terus mengintensifkan kegiatannya, menyebar mubalig ke daerah, meningkatkan kepedulian di sektor ekonomi dan secara konsisten memperaktekan prinsip ajarannya melalui sholat, dan dalam pola prilaku sehari hari. 